\title{
The Development of Demische Software to Detect and Reduce Misconception in Chemical Equilibrium through Conceptual Change Text Strategy
}

\author{
Lifia Ramadhani \\ Chemistry Department \\ Universitas Negeri Surabaya \\ Surabaya, Indonesia
}

\author{
Sukarmin \\ Chemistry Department \\ Universitas Negeri Surabaya \\ Surabaya, Indonesia \\ sukarmin@unesa.ac.id
}

\author{
Utiya Azizah \\ Chemistry Department \\ Universitas Negeri Surabaya \\ Surabaya, Indonesia
}

\begin{abstract}
This research is used to obtain Demische (Decreasing misconception in chemical equilibrium) software that is proper through conceptual change text strategy that is developed as learning media to detect and reduce misconception in chemical equilibrium 11th grade. Software feasibility can be known by three aspects that are (1) software validity based on content and construct validity, (2) practicality based on student response questionnaire supported by student observation activities, (3) effectiveness based on shifting understanding of student conceptions from misconceptions to knowing the concepts. This research uses Research and Development (R\&D) method based on Borg and Gall, with 12 subject that are the students of 11th grade at Senior High School 1 Pandaan, Pasuruan in Indonesia who have studied chemical equilibrium and have potential to misconception. The result shows that Demische software was used to detect and reduce misconception through conceptual change text strategy in chemical equilibrium which can be known by three aspects that are (1) the average percentage of content validity is $83,06 \%$ and construct validity is $85,60 \%$, both of validity are categorized as highly valid; (2) the average percentage of student response is $91,11 \%$ and categorized as highly practical; (3) the average percentage of effectiveness based on shifting understanding of student conceptions from misconceptions to knowing the concepts is $84,92 \%$ and categorized as highly effective. Based on the result, Demische software is proper to detect and reduce misconception in chemical equilibrium.
\end{abstract}

Keywords-software, misconception, conceptual change text, chemical equilibrium

\section{INTRODUCTION}

Education is one of the most important elements in human life to create a qualified generation of quality to be able to compete in globalization era. This affects to the development of education which is in line with changes in all aspects of life. For this reason, to improve the quality of education needs to be done, so it can keep up with the demands of the times.

Improving the quality of education aims to achieve graduate competence in an effort to create national education goals. Based on the Minister of Education and Culture Regulation Number 21 Year 2016 concerning the Standard of Primary and Secondary Education Content, to achieve graduate competency it is necessary set Content Standards as criteria regarding the scope of material and the level of competency of students. The goal of making this happen so that students have the skills needed in the 21 st century, namely learning and innovation skills include critical thinking skills, being able to solve problems, creative and innovative, able to communicate and collaborate, and skilled in using media, technology, information and communication. One of the learning principles that can be used to make national education goals comes true is to utilize information and communication technology to improve learning efficiency and effectiveness [1].

Along with the development of science and technology, technological advancements are expected to help to realize the learning process in accordance with the principles of learning by utilizing existing technology. The development of the use of information and communication technology, there are five shifts in the learning process, namely: 1) from training to appearance, 2) from classrooms to where and anytime, 3) from paper to "online" or channel, 4) from physical facilities to network facilities, 5) from cycle time to real time. To make it happen, it is necessary to develop the ability and creativity of educators in creating meaningful learning activities [2].

Likewise in studying chemistry, a student needs to find the right method to understand the material because chemistry has many concepts that may confusing. Chemistry is a branch of science that studies the properties, structure, matter, composition, change, and energy that cause changes in matter. In chemistry subjects, students are not only faced with abstract concepts, but also underlying symbols and theories. Some examples of material in chemistry subjects that have abstract concepts, including chemical bonds, chemical equilibrium, acid base, electrochemistry, and so forth. So students must really understand it.

Chemical equilibrium is one of the material in chemistry which contains abstract concepts. Students who are less active in the learning process, because low levels of student understanding of the material and have an impact on learning outcomes that are less than optimal. The low level of understanding to understand a material is the beginning of the emergence of misconceptions in students. From some previous studies, it can be seen that chemical equilibrium material has the potential to cause misconceptions in students.

Misconception is an illustration of a concept that is wrong or not in accordance with the concept put forward by experts in the field. Students who experience misconceptions can also be caused because students have difficulty 
understanding a complex concept [3]. Misconceptions can be viewed from two points of view. The first point of view is where this misconception arises. This point of view will provide signs to the teacher to be aware of things that allow misconceptions before and during the learning process to take place. The second point of view is the concept component of the misconception itself. This gives the teacher signs to be aware of things that allow misconceptions during the learning process. Misconceptions affect students' further learning negatively. Therefore, it is more important to be given when teaching to change misconceptions and support meaningful learning [4].

Several successful remediation methods and techniques have been documented in the literature to overcome misunderstandings, and to promote conceptual change using concept maps, animations, analogies, computer assistant simulations, conceptual change text, and laboratory activities [5].

Conceptual change text (CCT) is a text specifically designed to address and remediate misconceptions in students. Conceptual change text is different from traditional textbooks because it can help students reflect on their thoughts and realize their possible weaknesses [6]. The conceptual change text strategy that combines images, examples, and explanations can make it more effective in reducing student misconceptions [7]. Based on previous research, CCT strategy is effective to reduce misconceptions in students. In the results of the research with conceptual change text on chemical equilibrium material, students who experienced misconception changed their status to know the concept as much as $76.3 \%$; students who experience misconception change their status to not know the concept by $2 \%$; and $21.7 \%$ of students are still misconceptions [8].

Based on the pre-research results at Senior High School 1 Pandaan, Pasuruan on the concept of dynamic equilibrium showed that $36 \%$ of students' misconceptions, the concept of equilibrium constant showed that $27 \%$ of students' misconceptions, and Le Chatelier's principles shows that $24 \%$ of students' misconception. Based on re-research results in Islamic Senior High School 1 Gresik on the concept of dynamic equilibrium showed that $74 \%$ of students' misconceptions, the concept of equilibrium constant shows that $71 \%$ of students' misconceptions, and Le Chatelier's principles showed that $81 \%$ of students misconception. The pre-research results at Senior High School Jogoroto, Jombang on the concept of dynamic equilibrium showed that $50 \%$ of students misconceptions, the concept of equilibrium constant showed that $56 \%$ of students misconceptions, and Le Chatelier's principles showed that $43 \%$ of students misconception.

The result of pre-research is supported by the research that shows most of students' misconceptions in the approach of equilibrium, the characteristic of equilibrium by the concentrations of product and reactant, also the rate to the right and left, the value of equilibrium constant, and equilibrium shifting [9].

To reduce misconceptions in students' media is needed in learning. Media in learning is one of the tools in learning that can facilitate students in the teaching and learning process and can be used in reducing misconceptions in students. The role of learning media is very important as an intermediary in effective communication between teachers and students. Differences in the level of understanding in students requires teachers to be more creative in delivering material and can condition students well and create in a fun class. The use of learning media requires a teacher who can harmonize between the media and the learning methods used.

The instrument used to detect misconceptions, especially in chemical equilibrium materials, has not been widely developed. In general, it is still a manual test and takes longer to analyze. The use of computers as an instrument can be used to facilitate teachers in detecting and reducing misconceptions in students. Software development can be used to detect and reduce misconception that can be seen from the obtained result [10]. Thus the development of media in the form of software needs to be held to detect the presence or absence of misconceptions in students and the extent to which students experience misconceptions in the chemical equilibrium material of $11^{\text {th }}$ grade, so that misconceptions in students can be resolved more quickly.

\section{METHODS}

This research is used Research and Development (R\&D) method which has 10 steps that can be known in the Figure 1.

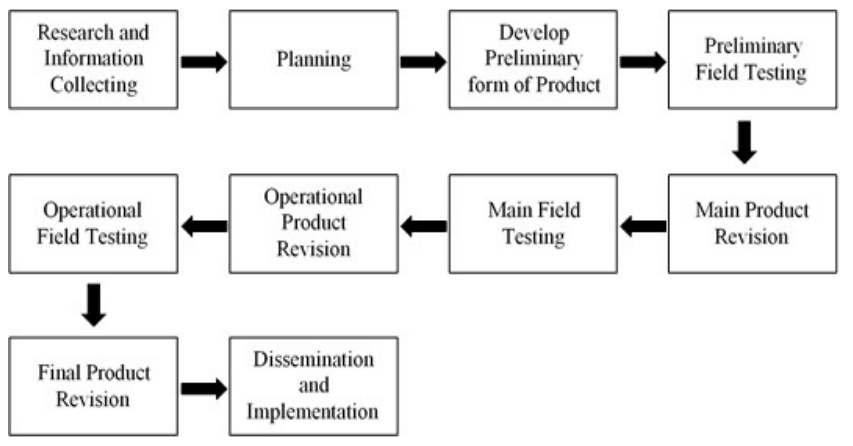

Fig. 1. Research and Development (R\&D) method [11]

In this research is limited to the fifth step that is main product revision. Demische software will be tested on 12 students of 11th grade at Senior High School 1 Pandaan, Pasuruan who have studied chemical equilibrium. The target of this research is detector and reductor Demische software in chemical equilibrium matter through conceptual change text strategy. Demische software consist of pretest that use to detect pre-concept of students, CCT that use to reduce misconception, and post test that use to know the shifting of student's conception.

This research uses some instruments to know the feasibility of Demische software. The instrument of this research are review questionnaire sheet, validation sheet, observation sheet of student activity, test sheet (preliminary research, pretest, and post test), and student response questionnaire sheet. To get the data in this research is collected through questionnaire and test methods. Questionnaire method which is used include review questionnaire sheet, validation sheet, student response questionnaire sheet, and observation sheet of student activity. Then, test method which is used include the test of preliminary research, pretest, and posttest. After developing Demische software, the next is reviewing the content to get criticism and suggestions from reviewer who is one 
chemistry lecturer. By the criticism and suggestions, the revision are made to improve the software.

After reviewing the content, the next is validation process in the terms of content and construct validity that given to three validators which are two chemistry lectures and one chemistry teacher. The validators are giving assessment scores in the range of 1-5 based on Likert scale in accordance with the validation sheet.

TABLE I. LIKERT SCALE

\begin{tabular}{|c|c|}
\hline Score & Category \\
\hline 1 & Very bad \\
\hline 2 & Bad \\
\hline 3 & Good enough \\
\hline 4 & Good \\
\hline 5 & Very Good \\
\hline
\end{tabular}

The validity is calculated by using a formula:

$$
\text { Validity }(\%)=\frac{\sum \text { total score }}{\sum \text { criteria score }} \times 100 \%
$$

$\Sigma$ total score $=$ the sum scores which are gotten from the validators and $\Sigma$ criteria score $=$ the sum of the highest scores of each item times to number of item times to number of validators

The percentage of data scores from validation result is interpreted to Likert Scale. The results of the assessment of the validity scores that have been obtained are interpreted to the category as in Table II.

TABLE II. INTERPRETATION SCORE OF VALIDITY

\begin{tabular}{|c|c|}
\hline Percentage (\%) & Category \\
\hline $0-20$ & Invalid \\
\hline $21-40$ & Less valid \\
\hline $41-60$ & Valid enough \\
\hline $61-80$ & Valid \\
\hline $81-100$ & Very Valid \\
\hline
\end{tabular}

[12]

Based on Table II, Demische software stated valid in the terms of content and construct validity if it gets minimum valid criteria or $\geq 61 \%$ in each validity [12]

The next stage is preliminary field testing to do limited trial test after Demische software stated valid from both of content and construct validity. At this stage is used to get data of practicality and effectiveness of Demische software. Practicality can be seen by student response which is supported by the observation of student activity when they do trial test. Then, effectiveness can be seen by shifting understanding of student conceptions from misconceptions to knowing the concepts.

The practicality of Demische software is viewed by the result of 12 students' responses as trial subject supported by the observation of students' activity during the limited trial process. The result of students' responses and the observation of students' activity are analyzed by using the Guttman scale.

TABLE III. GUTTMAN SCALE

\begin{tabular}{|c|c|c|}
\hline \multirow{2}{*}{ Answer } & \multicolumn{2}{|c|}{ Score } \\
\cline { 2 - 3 } & Positive Statement & Negative statement \\
\hline Yes & 1 & 0 \\
\hline No & 0 & 1 \\
\hline
\end{tabular}

The percentage of students' responses and the observation of students' activity are analyzed by the following formula:

$$
\mathrm{P}(\%)=\frac{\sum \text { responden score }}{\Sigma \text { criteria score }} \times 100 \%
$$

Then, the percentage is interpreted to interpretation score criteria which is shown in Table IV.

TABLE IV. INTERPRETATION SCORE OF PRACTICALITY

\begin{tabular}{|c|c|}
\hline Percentage (\%) & Category \\
\hline $0-20$ & Impactical \\
\hline $21-40$ & Less practical \\
\hline $41-60$ & Practical enough \\
\hline $61-80$ & Practical \\
\hline $81-100$ & Very practical \\
\hline
\end{tabular}

[12]

Based on the interpretation criteria of the score, Demische software can be stated practical if it gets a percentage $\geq 61 \%$ that categorized as practical.

The effectiveness of Demische is analyzed by shifting understanding of student conceptions from misconceptions to knowing the concepts. To know the shifting of student conception, it's used three tier diagnostic test. There are some category of conception by three tier diagnostic test that can be known in Table V.

TABLE V. CONCEPTION CATEGORY

\begin{tabular}{|c|c|c|c|}
\hline $\mathbf{1}^{\text {st }}$ Tier & $\mathbf{2}^{\text {nd }}$ Tier & $\mathbf{3}^{\text {rd }}$ Tier & Category \\
\hline Correct & Correct & Confident & Knowing concept (K) \\
\hline Correct & Incorrect & Confident & Misconception 1 (M1) \\
\hline Incorrect & Correct & Confident & Misconception 2 (M2) \\
\hline Incorrect & Incorrect & Confident & Misconception 3 (M3) \\
\hline Correct & Correct & Not confident & Lack of knowledge (L) \\
\hline Correct & Incorrect & Not confident & Lack of knowledge (L) \\
\hline Incorrect & Correct & Not confident & Lack of knowledge (L) \\
\hline Incorrect & Incorrect & Not confident & Lack of knowledge (L) \\
\hline
\end{tabular}

Demische is stated effective if the percentage of the shifting understanding of student conceptions from misconceptions to knowing the concepts gets $\geq 61 \%$ through interpretation score in Table VI. 
TABLE VI. INTERPRETATION SCORE OF EFFECTIVENESS

\begin{tabular}{|c|c|}
\hline Percentage (\%) & Category \\
\hline $0-20$ & Ineffective \\
\hline $21-40$ & Less effective \\
\hline $41-60$ & Effective enough \\
\hline $61-80$ & Effective \\
\hline $81-100$ & Very effective \\
\hline
\end{tabular}

[12]

\section{RESULT AND DISCUSSION}

The result and discussion about this research is presented the validity of software, students' response during the trial, and the shifting of students' conception after operates the software.

\section{A. Validity of Demische Software}

Validation is used to know the validity to determine the feasibility of Demische software that has been developed. There are two kinds of validity that are content and construct validity.

Based on the results of the assessment that has been carried out by three validators that are two chemistry lectures and one chemistry teacher obtained the percentage of content is shown in Table VII.

TABLE VII. CONTENT VALIDITY RESUlt

\begin{tabular}{|l|c|c|}
\hline \multicolumn{1}{|c|}{ Criteria } & Percentage (\%) & Category \\
\hline $\begin{array}{l}\text { Conformity of test } \\
\text { question }\end{array}$ & 86.67 & Highly valid \\
\hline Conformity of materials & 86.67 & Highly valid \\
\hline Conformity of figure & 80 & Valid \\
\hline Conformity of video & 80 & Valid \\
\hline Conformity of animation & 80 & Valid \\
\hline $\begin{array}{l}\text { Conformity of CCT } \\
\text { strategy to reduce } \\
\text { misconception }\end{array}$ & 85 & Highly valid \\
\hline
\end{tabular}

Based on the Table VII, can be known the percentage of content validity which has 6 criteria. The first criteria is used to know the conformity of test questions include the conformity with the aim, basic competence, the quality of the questions, and the ability of question to detect students' conception. The second criteria is used to know the conformity of materials include the conformity of material that is relevant with the test and the correctness of writing symbols, equations, and number. The third criteria is used to know the conformity of figure include the relevance of figure to the materials and the clarity of figure. The fourth criteria is used to know the conformity of video include the relevance of video to the materials and the clarity of video. The fifth criteria is used to know the conformity of animation include the relevance of animation to the materials and the clarity of animation. The sixth criteria is used to know the clarity of CCT strategy to reduce student's misconception include there are questions to show student's conception, component to make conceptual conflict, component to change students' conception, and component to reconstruction students' concept. Content validity result gets the average percentage of $83.06 \%$ and categorized to be highly valid. It means that the questions, material, and CCT strategy is proper to use.
The result of construct validity that also has been carried out by three validators is shown in Table VIII.

TABLE VIII. CONSTRUCT VALIDITY RESUlT

\begin{tabular}{|l|c|c|}
\hline \multicolumn{1}{|c|}{ Criteria } & Percentage (\%) & Category \\
\hline $\begin{array}{l}\text { Feasibility of language } \\
\text { usage }\end{array}$ & 86.67 & Highly valid \\
\hline Easiness of usage & 80 & Valid \\
\hline $\begin{array}{l}\text { Accuracy of result } \\
\text { analysis }\end{array}$ & 90 & Highly valid \\
\hline
\end{tabular}

Based on the Table VIII, can be known the percentage of construct validity which has 4 criteria. The first criteria is used to know the visual quality include choosing background, font, size of font, font colour, layout, colour composition of visual, and the accuracy of button usage. The second criteria is used to know the feasibility of language usage includes language usage both of questions test and $\mathrm{CCT}$, the clarity of language, and does not cause multiple interpretations. The third criteria is used to know the easiness of software usage. The fourth criteria is used to know the accuracy of result analysis includes the rapidity of analysis and the accuracy of the result. Construct validity result gets the average percentage of $85.60 \%$ and categorized to be highly valid. It means that the visual, language usage, easiness usage, and accuracy of result analysis is proper to use.

\section{B. Practicality of Demische Software}

To determine the practicality of Demische software as media to detect and reduce misconception in chemical equilibrium material can be known by the result of students' response and it is supported by the observation of students' activity.

The result of students' response is gotten by the questionnaire that have been given to 12 students' which are doing the trial of Demische software. From the questionnaire can be known the percentage of students' response. Demische software is stated practical if it gets the average percentage of $\geq 61 \%$. The result is shown by Fig. 2 .

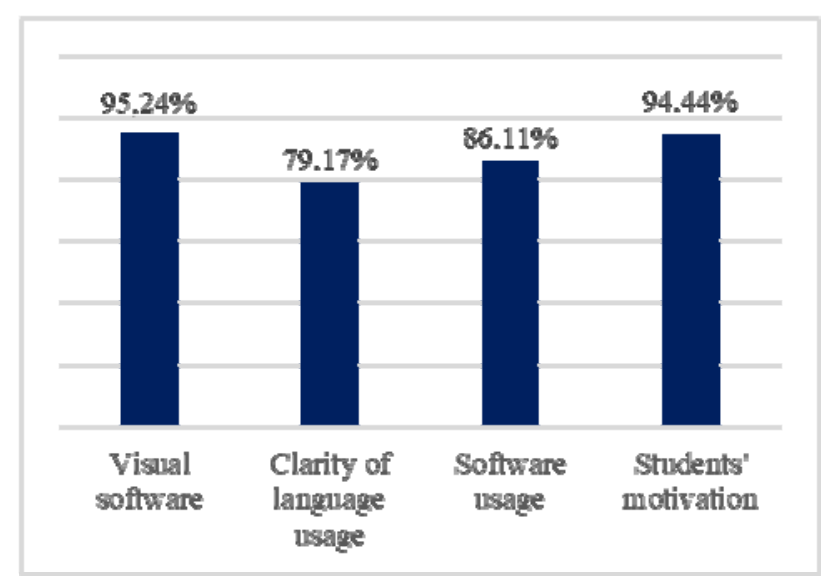

Fig. 2. Students' response

Based on Figure 2 above, the result of student's response get the average percentage of $91.11 \%$ and categorized as highly practical to use. The result of students' response is 
supported by the observation of students' activity in trial of Demische software.

\section{Effectiveness of Demische Software}

To determine the effectiveness of Demische software as media to detect and reduce misconception in chemical equilibrium material can be known by the shifting of students' conception from misconception to knowing the concept. The result is gotten by software output that is the shifting of students' conception from misconception to knowing the concept.

The result of the conceptual shift experienced by students after working on the problem and reading conceptual change text is the output of the software. Based on the objectives of developing this software, namely to reduce students' misconceptions in chemical equilibrium material. The results of the student's conception shift were obtained from the results of the work on the pretest and post test questions which were compiled using the three tier diagnostic test method. The pretest problem is used to detect students' initial conception, whether students experience misconception (M), do not know the concept (L), or know the concept (K), while the post test question is used to determine the shift in conception. Students' who know the concept are students who choose answers and reasons that support correctly and are confident in answering the question. Students who do not know the concept are students who are not sure in answering the questions even though the answers and reasons given are correct. Students who experience misconception have 3 categories, namely M1, M2, and M3. Students who experience M1 are students who give the right answers and the wrong reasons but students are confident in answering these questions. Students who experience M2 are students who give wrong answers and correct reasons but students are confident in answering these questions. Students who experience M3 are students who give wrong answers and reasons and answer confidently [13].

The conception shift that occurs is mostly from the $\mathrm{M}$ to $\mathrm{K}$ which is indicated by the data resulting from the shift in students' conceptions in Table IX.

TABLE IX. STUDENTS' CONCEPTIONS SHIFT

\begin{tabular}{|c|c|c|c|c|c|c|c|c|c|}
\hline \multirow{3}{*}{ Shifting } & \multicolumn{9}{|c|}{ Concept } \\
\hline & \multicolumn{3}{|c|}{$\begin{array}{c}\text { Dynamic } \\
\text { Equilibrium }\end{array}$} & \multicolumn{3}{|c|}{$\begin{array}{c}\text { Equilibrium } \\
\text { Constant }\end{array}$} & \multicolumn{3}{|c|}{$\begin{array}{c}\text { Le Chatelier } \\
\text { Principle }\end{array}$} \\
\hline & 1 & 2 & 3 & 1 & 2 & 3 & 1 & 2 & 3 \\
\hline $\mathrm{K}-\mathrm{K}$ & 6 & 1 & 0 & 2 & 1 & 4 & 4 & 2 & 3 \\
\hline $\mathrm{K}-\mathrm{L}$ & 0 & 0 & 0 & 0 & 0 & 0 & 0 & 0 & 0 \\
\hline $\mathrm{K}-\mathrm{M}$ & 0 & 0 & 0 & 1 & 0 & 0 & 0 & 0 & 0 \\
\hline$L-K$ & 1 & 0 & 0 & 0 & 3 & 0 & 1 & 0 & 0 \\
\hline$L-L$ & 0 & 1 & 0 & 0 & 0 & 0 & 1 & 0 & 1 \\
\hline $\mathrm{L}-\mathrm{M}$ & 0 & 0 & 1 & 0 & 0 & 0 & 0 & 1 & 0 \\
\hline$M-K$ & 4 & 9 & 9 & 7 & 7 & 7 & 5 & 8 & 7 \\
\hline$M-L$ & 1 & 0 & 2 & 2 & 1 & 1 & 1 & 0 & 0 \\
\hline$M-M$ & 0 & 1 & 0 & 0 & 0 & 0 & 0 & 1 & 1 \\
\hline
\end{tabular}

Based on the data from the percentage shift in conception of students in Table IX, it can be seen that there is a shift in student conceptions. In the concept of the first dynamic equilibrium problem, students who did not experience a shift in conception and still knew the concept of 6 students. The shift in conception that occurred from L-M (lack of knowledge or did not know the concept to misconception) had only one student, from M-K (misconception to knowing the concept) to 4 students, and from M-L (misconception to not knowing the concept) there was only 1 student. On the second question, students who did not experience a shift in conception were 3 students in which 1 student remained $\mathrm{K}, 1$ student remained in kindergarten, and 1 student remained $\mathrm{M}$. The shift in conception that occurred from $\mathrm{M}-\mathrm{K}$ was 9 students. On the third question, the shift in conception that took place from L-M had only 1 student, from M-K as many as 9 students, and from M-L as many as 2 students.

In the concept 2 of the first question equilibrium constants, students who did not experience a shift in conception were 2 students where students still knew the concept. The shift in conception that occurred from K-M had only 1 student, from $\mathrm{M}-\mathrm{K}$ as many as 7 students, and from M-L as many as 2 students. On the second question, students who did not experience a shift in conception there was only 1 student where students still knew the concept. The shift in conception that occurred from L-K was 3 students, from M$\mathrm{K}$ as many as 7 students, and from M-L there was only 1 student. On the third question, students who did not experience a shift in conception were 4 students where students still knew the concept. The shift in conception that occurred from M-T was 7 students and from M-L only 1 student.

In Le Chatelier's 3 principles, the first question is that students who do not experience a shift in conception are 5 students where 4 students still know the concept and 1 student still does not know the concept. The shift in conception that occurred from L-K was only 1 student, from $\mathrm{M}-\mathrm{K}$ as many as 5 students, and from M-L only 1 student. In the second question, students who did not experience a shift in conception were 3 students where 2 students still knew the concept and 1 student still had a misconception. The shift in conception that occurred from L-M was only 1 student and from the $\mathrm{M}-\mathrm{K}$ there were 8 students. On the third question, students who did not experience a shift in conception were 5 students where 3 students still knew the concept, 1 student still did not know the concept and 1 student still had a misconception. The shift in conception that occurred from $\mathrm{M}-\mathrm{K}$ was 7 students.

The percentage of conception shifts from $M-K$ on the three concepts of chemical equilibrium are made in a diagram that can be seen in Figure 3.

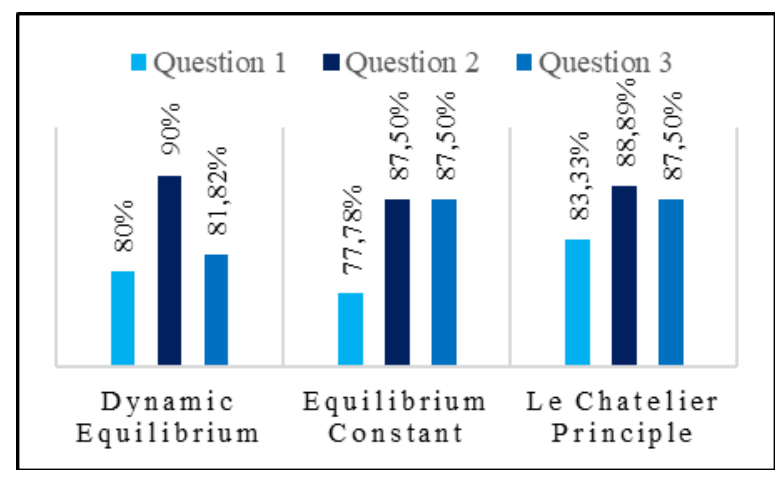

Fig. 3. Shifting of students' conception from $\mathrm{M}-\mathrm{K}$ 
Demische software that was developed said to be effective in reducing misconceptions if the results of the percentage of students who experienced a shift in conceptions from misconceptions became known to the concept of $\geq 61 \%$. Based on the diagram shown in Figure 3 the shift in students' conceptions of $\mathrm{M}-\mathrm{K}$ on the concept of dynamic equilibrium was $83.94 \%$ which was included in the very effective category. The first question obtains the percentage of students' conception shifts by $80 \%$, the second question is $90 \%$, and the third question is $81.82 \%$. In the second question, the highest percentage is obtained, because students are facilitated by the choice of answers in the form of images and in conceptual change text the third stage of concept 1 has also been described graphs that support equilibrium reactions.

The percentage of students' conception shifts from M-K to the concept of equilibrium constant of $84.26 \%$ which is included in the very effective category. The first question obtained the percentage of students' conceptual shifts of $77.78 \%$, second and third questions respectively at $87.50 \%$. In the first question, the lowest percentage was obtained because some students experienced a shift in conceptions from the M-L even though the students' answers were actually correct, thus affecting the percentage obtained because only students who experienced a shift in conception from $\mathrm{M}-\mathrm{K}$

The percentage shift in conception of students from M-K to the Le Chatelier principle concept of $86.57 \%$ which is included in the very effective category. The first question obtained the percentage of students' conceptual shifts of $83.33 \%$, the second question was $88.89 \%$, and the third question was $87.50 \%$. The average percentage obtained in the three concepts is $84.92 \%$ which is included in the very effective category. This shows that Demische software is very effective in reducing students' misconceptions in chemical equilibrium material.

\section{CONCLUSION AND SUGGESTION}

\section{A. Conclusion}

Based on the data from the validation by two chemistry lecturers and one chemistry teacher, observations of student activities, student response questionnaires, and shifts in students' misconceptions that have been analyzed, it can be concluded that Demische software is suitable to detect and reduce student misconceptions as follows:

1) Validity: Demische's software development is stated to be valid based on the acquisition of the percentage of content validity of $83.06 \%$ with highly valid criteria and construct validity of $85.60 \%$ with highly valid criteria.

2) Practicality: Demische's software development is stated to be practical based on the acquisition of student response questionnaires with the percentage of students' response rate of $91.11 \%$ with highly practical criteria.

3) Effectiveness: Demische's software development is stated to be effective based on the acquisition of the results of the shift in misconception students became aware of the concept with an average percentage of $84.92 \%$ with highly effective criteria.

\section{B. Suggestion}

- The development of Demische software to detect and reduce students' misconceptions needs to be developed in other materials, so, it can be useful to detect and reduce misconception in other materials.

- This research is limited only to the main product revision stage after got the trial result, so, further research is needed.

- The use of LAN networks in Demische software is limited to PCs (Personal Computer) or laptops, so, it is expected that Demische software can be online and developed to make more client server can used at the same time. Then, it is expected to be used through Android.

\section{ACKNOWLEDGMENT}

This research was supported by chemistry department of Universitas Negeri Surabaya. Authors would thank to the reviewer and validators who provided comments that greatly improved the Demische software. Authors also thank to the staff, chemistry teacher, and 12 students of Senior High School 1 Pandaan, Pasuruan who provided opportunities to conduct the research at school.

\section{REFERENCES}

[1] emendikbud, Permendikbud No.21 Tentang Standar Isi Pendidikan Dasar dan Menengah. Jakarta: Kementrian Pendidikan dan Kebudayaan, 2016.

$[2]$

. Rosenberg, C. Schooler, C. Schoenbach, and F. Rosenberg, "Global self-esteem and specific self-esteem: different concept, different outcomes," American Aosiological Review vol. 60, pp. 141-156, 1995.

[3]

Sudarmo,"Miskonsepsi siswa SMA terhadap konsep-konsep kimia," Prosiding Seminar Nasional Kimia dan Pendidikan Kimia, 2009.

. Atasoy, H. Akkus, and H. Kaydayifci, "The effect of a conceptual change approach on understanding of students' chemical equilibrium concepts," Research in Science \& Technological Education vol. 27, pp. 267-282, 2009.

[5]

L. Westbrook and E. A. Marek, "A cross-age study of student understanding of the concept of diffusion," Journal of Research in Science Teaching vol. 28, pp. 694-660, 1991.

$[6]$

. I. Cetingul and O. Geban, "Understanding of acid-base concept by using conceptual change approach," Hacettepe University Journal of Education vol. 29, pp. 69-74, 2005.

[7]

Ozmen and A Naseriazar, "Effect of simulations enhanced v conceptual change texts on university students understanding of chemical equilibrium," Journal of Serbian Chemical Society vol. 83, 2018.

$[8]$

ualifah, Suyono, and Yuanita, "Mencegah misskonsepsi siswa pada kesetimbangan kimia menggunakan model inkuiri terbuka dan remediasi menggunakan strategi conceptual change," Pendidikan Sains Pascasarjana Universitas Negeri Surabaya vol. 3, pp. 306-313, 2013.

[9]

Bilgin, E. Uzuntiryaki, and O. Geban, "Student's misconcept the concept of chemical equilibrium," Education Science vol. 28, pp. 10-17, 2003. 
[10] uprianto and Sukarmin, "Pengembangan software pengukur tingkat konflik kognitif kimia," Unesa Journal of Chemical Education vol. 5, pp. 359-366, 2016.

[13] O. Arslan, C. Cigdemoglu, and C. Moesley, “A three-tier diagnostic
test to assess pre-service teachers' misconceptions about global
[11] . R. Borg and M. D. Gall, Educational Research Fourth Edition. New York: Longmann Inc., 1983.

[12]

iduwan, Skala Pengukuran Variabel-Variabel Penelitian. Bandung: Penerbit Alfa Beta, 2015.

warming, greenhouse effect, ozone layer depletion, and acid rain," International Journal of Science Education vol. 24, pp. 1667-1686, 2012 . 